\title{
Tests on a polyvinyl chloride pipe from an existing water distribution system
}

\author{
B. Kowalska ${ }^{1}$, A. Rudawska ${ }^{2}$ \& D. Kowalski ${ }^{1}$ \\ ${ }^{1}$ Department of Water Supply and Sewage Disposal, \\ Lublin University of Technology, Poland \\ ${ }^{2}$ Department of Production Engineering, \\ Lublin University of Technology, Poland
}

\begin{abstract}
The following paper presents mechanical strength test results of a $160 \times 9 \mathrm{~mm}$ PVC-U pipe, in the service of Municipal Water and Sewage Company since 1976, and the impact of the pipe material on the quality of water in contact. The water quality was evaluated in terms of the leaching of certain chemical elements from the pipe material to the water. Additional tests were carried out on the water obtained from different sections of the PVC-U plastics piping systems for the water supply. Chemical elements detection was performed with inductively coupled plasma optical emission spectrometry ICP-OES JY 238 Ultrace. Furthermore, the testing included the analysis of sediment found on the inside pipe wall, with the application of a Quanta 200 FEG Scanning Electron Microscope (SEM).

Migration tests showed a clear influence of the pipe material on water quality which was in contact with the PVC pipe. The highest recorded value of lead in water samples was $162.2 \mathrm{ppb}$ and significantly exceeded the allowable concentration of lead contained in Directive 98/83/EC of the European Union equal to $10 \mathrm{ppb}$. Leaching of this element from the pipe material into the water proves the use of lead compounds as stabilizers for the production of pipes. The study of the chemical structure by Infrared Spectrometry showed changes in the test samples, demonstrating the degradation of the material, however, without affecting its strength. But the degradation of the material may affect the migration of lead into the water. The analysis of sediment on the inside of the pipe wall allowed us to identify mainly calcium carbonates, oxides and hydroxides of iron and manganese and also sodium chloride. The elements
\end{abstract}


included in the sediment are also typical for the water supply distribution system discussed.

Keywords: PVC pipe, water quality, water distribution system.

\section{Introduction}

In recent years, high density polyethylene (HDPE) and unplasticised polyvinyl chloride (PVC-U), among other plastics, were the most commonly used structural materials in water distribution networks and systems, as well as in trenchless pipe rehabilitation. What is more, an estimated 70 per cent of new water distribution networks are HDPE or PVC-U pipes and their share is still increasing [1]. According to the International Water Association (IWA), data similar tendencies can be observed in Europe and in the world [2, 3].

Polyvinyl chloride has been applied in water distribution systems for over 70 years. Its popularity could be ascribed to a relatively low price, great strength parameters (PVC-U) pipes are three times as strong as HDPE pipes [4]), simple and uncomplicated network assembly and pipe surface smoothness even after years of operation or corrosion resistance [5]. Moreover, polyvinyl chloride is characterised by satisfactory to high processability, and displays great capacity for modification of properties.

Water distribution pipes are designed for extended service life. Research conducted in major Polish cities [6] shows that $50 \%$ of water distribution pipes have been in service for over 50 years, and that conduits of 25-50 years old constitute $30-45 \%$ of the total network length. Nowadays, plastic pipe manufacturers guarantee a service life of over 50 years, grounding their claims in laboratory tests and by extrapolating test results from a shortened timescale. Such tests are largely limited to determining long-term strength, understood as hoop stress in a pipe subjected to constant or cyclic internal pressure after a given time period. Laboratory tests commonly focus on measuring hoop stress in the pipe wall, at an elevated temperature and in the function of time until fracture. Extrapolation employs Arrhenius equation between applied load time and temperature [7].

Plastic pipes fractures can be categorised into ductile and brittle. The former is mainly determined by yield stress of the material; therefore, time to ductile fracture is the function of yield stress and hoop stress. The ductile fracture area is where fracture is initiated under the highest stress. Lower stresses at longer time periods cause the fracture to become brittle and the fracture area displays resistance to slow crack propagation (with insignificant plastic strain) [8]. Hydrostatic design stress is derived from the material's long-term hydrostatic strength (LTHS) or minimum required strength (MRS) [9, 10]. Furthermore, this factor determines maximum allowable pressure on pipes in service. In order to determine yield stress, classic tensile strength tests are performed on pipe sections or dog-bone shaped samples, which have been removed from the axial direction (down the length of the pipe) [11].

Plastics, such as PVC, are susceptible to degradation processes under load, temperature and other environmental factors. The process of degradation is 
manifested by gradual changes of the material's physical and chemical properties; for instance, discolouration or change of material strength indices. In the presence of oxygen and at an elevated temperature, polyvinyl chloride undergoes oxidation reactions, dehydrochlorination or cross-linking [12-15]. To counteract polymer degradation and to facilitate PVC processing, the application of such additives as, for instance, thermal and ultraviolet stabilisers or softening and release agents is required [16, 17]. Typical thermal stabilisers include: organotin compounds, such as carboxylates with tin-oxygen bonds or mercaptides with tin-sulphur bonds (e.g. Irgastab T, TK, 17 MOK, Ergoterm BMB-S). Other thermal stabilisers that ought to be mentioned are cadmium, calcium, barium, strontium, magnesium, zinc or fatty acid salts. The group of lead stabilisers includes sulphates, phthalates or phosphates, such as Interstab L (Akzo-Chemie Interstab) [18]. These compounds can, however, migrate to water in contact with pipe material and be of detrimental effect on water quality. Compound migration from PVC pipe material to water, of e.g. polyvinyl chloride monomer, lead or organotin compounds, has been the subject of numerous research by, inter alia, Sadiki et al. [19], Al-Malack [20], Al-Malack and Sheikheldin [21], Lasheen et al. [22] and Kowalska et al. [23].

The primary objective of the present research was to determine basic mechanical properties of a $160 \times 9 \mathrm{~mm}$ PVC-U pipe, which has been in the service of Municipal Water and Sewage Company since 1976 as well as to evaluate the impact of the pipe material on the quality of the water in contact. Water quality was established in terms of leaching of certain chemical elements from the material of the pipe to water in accordance with European Standard EN 12873-1 [24], which finds application in new plastic pipe testing. Water samples obtained from a still-in-service 1976 PVC-U pipe network section were analysed. In addition, conducted tests included the analysis of sediment accumulated on the inside wall of the pipe sample with the application of Quanta 200 FEG scanning electron microscope (SEM).

\section{Test description and methodology}

\subsection{Strength and structural tests}

Basic mechanical properties tests of PVC-U specimens were conducted as per EN ISO 527-1:1998 Standard [25] on a Zwick Roell Materials Testing Machine at Lublin University of Technology laboratory. Sample conditioning and testing were carried out in normalised conditions, i.e. at $23 \pm 2^{\circ} \mathrm{C}$, at $50 \pm 10 \%$ relative humidity, in accordance with EN ISO 291:2008 Standard [26]. To determine tensile strength, the specimen was pulled at a test speed of $50 \mathrm{~mm} / \mathrm{min}$. Determination of Young's modulus was conducted at a test speed equal to $1 \mathrm{~mm} / \mathrm{min}$. Normalised dog-bone shaped samples were removed from $160 \mathrm{x}$ $9 \mathrm{~mm}$ PVC-U pipe material from the axial direction (down the length of the pipe). Figure 1 presents the specimens and their dimensions.

Chemical structure tests were performed with infrared spectroscopy on Thermo Scientific Nicolet iS10 FT-IR spectrometer. IR spectra were recorded at 


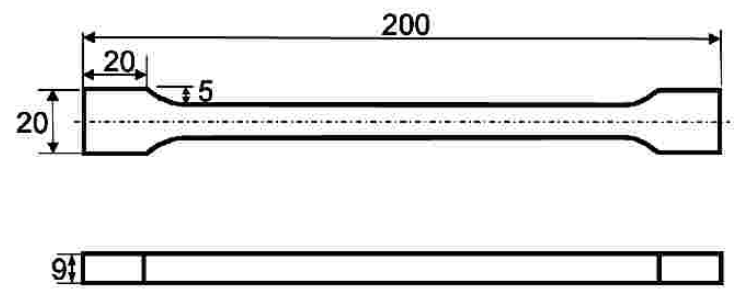

Figure 1: $\quad$ Test specimens and their dimensions.

three random points on the $2 \times 2$ specimens, extracted from the pipe surface. The samples were then cut in thickness and their spectra, of internal (zew_wew) and external wall of the analysed pipe (wew_wew), were subsequently acquired with a diamond ATR crystal. Each spectrum was obtained by 32-fold scanning taken at $4 \mathrm{~cm}^{-1}$ resolution in the range of $500 \mathrm{~cm}^{-1}$ to $4000 \mathrm{~cm}^{-1}$.

\subsection{Water and sediment analysis}

The next stage of tests comprised analyses aimed at evaluating the impact of pipe material, following long-term service, on the quality of water in contact with the inside surface of the pipe. This examination task consisted of determining in water samples trace elements which could be indicative of the presence of stabilisers and other auxiliary substances added to PVC in the production process. Test material comprised an extracted fragment of a pipe in service since 1976, which arrived in Environmental Analysis Laboratory of Lublin University of Technology for experimental tests. The tests in question were conducted in accordance with EN 12873-1 Standard, applied in new pipe testing. A section of the pipe was cut into test specimens, carefully rinsed in tap water to remove any sediment and to prepare samples for migration tests as per EN 12873-1:2005 Standard. Prior to testing samples were subjected to another rinsing with sterile deionised water (conductivity of $<2 \mathrm{mS} / \mathrm{m}$ and organic carbon content of $<0.2 \mathrm{mg} / \mathrm{dm}^{3}$ ). Rinsed pipe fragments were placed in a glass container, covered with deionised water, the use of which was to prevent the influence of tap water on test results. The desired pipe specimen surface to water volume ratio would amount to approximately $15 \mathrm{dm}^{-1}$ and immersion period of $72 \mathrm{~h}$ at ambient temperature $(23 \pm 2)^{\circ} \mathrm{C}$. Following the immersion period, the water from the containers was poured into glass bottles and subjected to further tests. The whole procedure was repeated three times.

Elements detection involved the application of inductively coupled plasma optical emission spectrometry ICP-OES JY 238 Ultrace (Horiba Jobin Yvon). Spectrum images were acquired with ICP V5 ver. 1.0 software (for highprecision elements determination). ICP-OES calibration was performed with ICP multi-element standard solution CertiPUR ${ }^{\circledR}$ VIII (Merck). The following emission wavelengths were selected: As $193.695 \mathrm{~nm}, \mathrm{Cd} 228.802 \mathrm{~nm}, \mathrm{Cu}$ $223.008 \mathrm{~nm}$, Fe $259.940 \mathrm{~nm}$, Mn $257.610 \mathrm{~nm}, \mathrm{~Pb} 220.353 \mathrm{~nm}$ and $\mathrm{Zn}$ $213.856 \mathrm{~nm}$. In all measurements, the background signal was taken into 
consideration. A four-point calibration curve, analysis mode Max (5/3) and $2 \mathrm{~s}$ integration time were accepted together with a quantitative detection method with an external calibration curve. ICP multi-element standard solutions VI and VIII (Merck ICP Standard) were applied. Prior to testing, the samples were acidified in $\mathrm{HNO}_{3}\left(\mathrm{POCH} 65 \%\right.$ ULTRANAL ${ }^{\circledR}$ ).

The analysis comprised the following: a Czerny-Turner monochromater, a $1 \mathrm{~m}$ focal length, a vertical plasma, a $1000 \mathrm{~W}$ generator, $12 \mathrm{l} / \mathrm{min}$ plasma gas flow, auxiliary gas flow $0 \mathrm{l} / \mathrm{min}$, shielding gas flow $0.2 \mathrm{l} / \mathrm{min}$, nebulisation $0.7 \mathrm{l} / \mathrm{min}$ at the pressure of $2.80 \mathrm{bar}$, sample flow rate $1 \mathrm{ml} / \mathrm{min}$, nebuliser - Mira Mist, Scott-type spray chamber.

\section{PVC-U mechanical properties: selected tests}

The tests aimed at determining the tensile strength of the sample material, elongation at break as well as longitudinal modulus of elasticity, i.e. Young's modulus (the test results are presented in Table 1). Due to the lack of any technical specifications from the pipe manufacturer which would date back to 1976 - the year of production - a 1980 catalogue served as the point of reference (marked in the table as Lit), together with own tests conducted on samples extracted from a pipe of identical, in terms of geometry, characteristics to that of the 1976 pipe specimen and of similar chemical composition. In the table, the results are marked as NP.

Table 1: $\quad$ Strength test results of PVC-U pipe samples.

\begin{tabular}{|c|c|c|c|}
\hline No. & Tensile strength, MPa & Elongation at break, \% & Young's modulus, GPa \\
\hline 1 & 52.6 & 33 & 2.7 \\
\hline 2 & 45.6 & 19 & 3.0 \\
\hline 3 & 51.4 & 25 & 2.8 \\
\hline 4 & 52.5 & 21 & 2.7 \\
\hline 5 & 52.4 & 21 & 2.7 \\
\hline Lit* & $50-60$ & $10-20$ & 3.0 \\
\hline NP** & $48-53$ & 51 & 2.7 \\
\hline
\end{tabular}

*1980 manufacturer specifications, **NP - new pipe.

The test results presented in Table 1 indicate that basic strength parameters of the analysed PVC-U pipe were not subjected to substantial change as compared with literature or new pipe data. Polyvinyl chloride pipes tend to manifest increase in strength values when in contact with chlorinated water, as it is hardened and strengthened through the acquisition of additional chlorine atoms into the pipe material structure. Operating water distribution networks are disinfected with chlorine compounds on a regular basis, which could be the factor influencing their excellent results after 40 years of service; e.g. elongation 
at break values exceeded manufacturer specifications, however, were smaller than the values obtained in new pipe tensile strength tests. Available literature suggests that the range given by the manufacturer refers to unplasticised polyvinyl chloride in general, rather than a particular pipe. Decrease in elongation following years of service of PVC-U pipes is probably a result of its brittleness gradually increasing in time. In the case of Young's modulus, which describes stiffness of materials, obtained values were slightly discrepant, yet comparable to those acquired in new pipe strength tests. The differences might result from different failure points, as evidenced in Fig. 2.

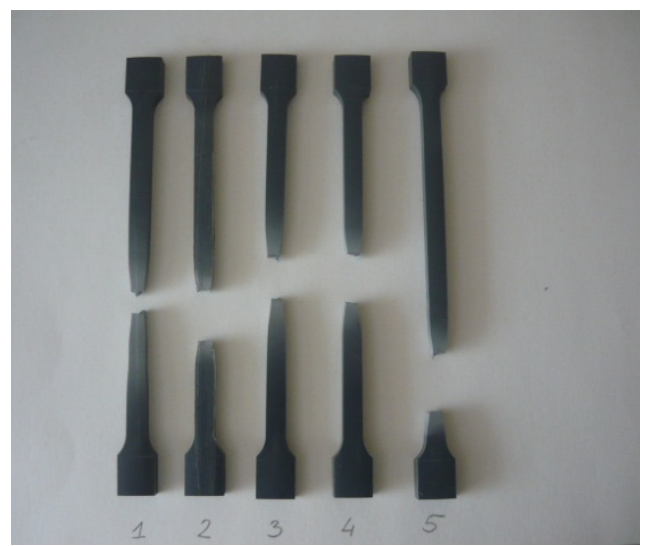

Figure 2: Test samples after tensile testing to failure.

\subsection{Chemical structure tests}

IR spectroscopy was incorporated in research with the aim of providing analysis of the chemical structure of the sample material and to facilitate evaluation of material degradation. Infrared spectrometry, consisting of IR absorption analysis of a certain wavelength, enables analysis of oxidation products and polymer degradation.

The analyses allowed us to observe differences in the spectrum between the inner and outer layer of the polymer (Fig. 3). Degradation is predominantly connected with the outer polymer layer and conformational changes in its chain structure. The peak was observed at $1750 \mathrm{~cm}^{-1}(\mathrm{C}=\mathrm{O}$ stretching vibration) and $1640 \mathrm{~cm}^{-1}(\mathrm{C}=\mathrm{C}$ stretching vibration). The peak presence suggests degradation of polymer and the creation of new bonds as a result of oxidation. What can also be observed is the decrease in peak intensity, which is characteristic of deformation vibrations of $\mathrm{CH}_{2}$ groups in the wavelength of $1300-1450 \mathrm{~cm}^{-1}$. Peak intensity decrease in the area of $1430 \mathrm{~cm}^{-1}$ and $1330 \mathrm{~cm}^{-1}$ could be indicative of polymer chain degradation (mer degradation or branching). 


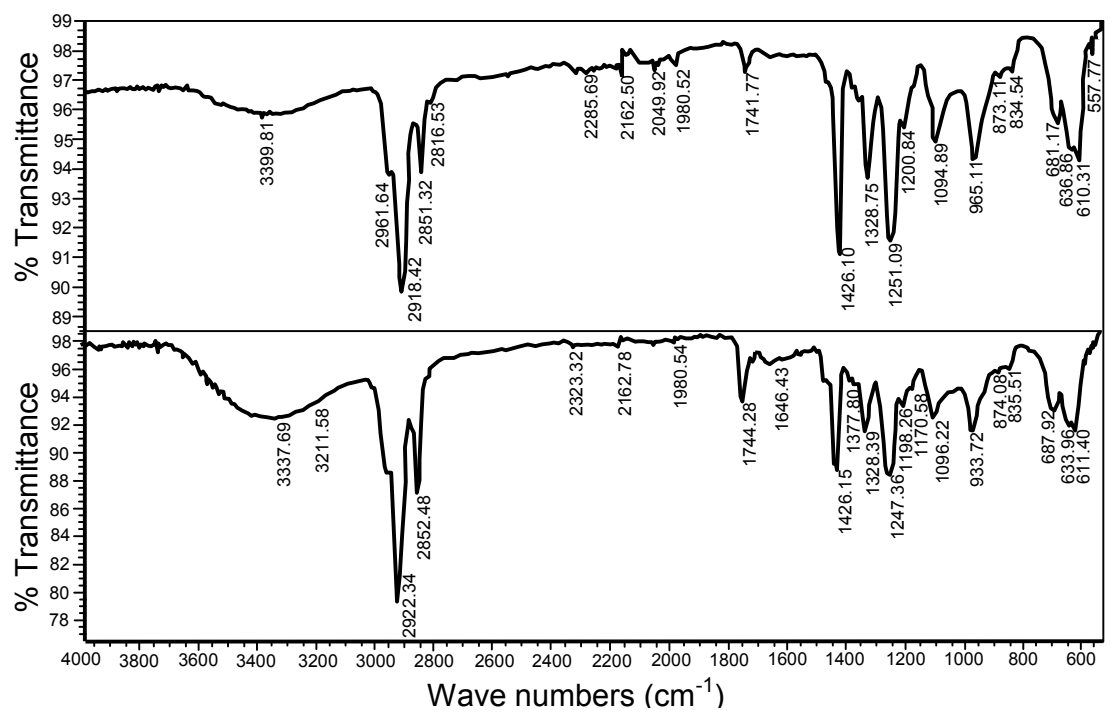

Figure 3: IR spectrum of PVC sample extracted from pipe. Comparison of outer (bottom spectrum) and inner (upper spectrum) layer.

\section{Laboratory and field tests of water in contact with PVC-U pipe material}

The water samples obtained as a result of subsequent migration tests, as per EN 12873-1 Standard [24], contained such elements as $\mathrm{Mn}, \mathrm{Pb}, \mathrm{Zn}$, as well as iron $(\mathrm{Fe})$, which was also noted following the first test (the results of analysis were collected in Table 2). Manganese and potassium constitute a major share of the sediment accumulated on the outside of the old pipe wall; nevertheless, their presence could result from insufficient rinsing of the pipe prior to testing. High lead concentration, particularly after the second test $\left(162.2 \mathrm{ppb}-0.16 \mathrm{mg} / \mathrm{dm}^{3}\right)$, indicates that lead compounds had been used in the pipe production process as stabilisers. Lead compounds, in widespread use in the 1970s, were cost-effective and efficient stabilisers and are to date used in plastic pipes. In Poland, the permissible lead level in potable water is established in the Minister of Health regulation of April 20, 2010 [27] and is equal to $0.025 \mathrm{mg} / \mathrm{dm}^{3}$, therefore here it was six times higher than the permissible limit of $162.2 \mathrm{ppb}\left(0.16 \mathrm{mg} / \mathrm{dm}^{3}\right)$.

The comparison of laboratory and field test results required the analysis of water from an existing PVC-U pipe water distribution network, from which the pipe material was extracted. To ensure high-precision evaluation of the impact of pipe material on water quality, water was sampled at two locations, at the beginning and at the end of an area composed of 1976 PVC-U pipes.

Water samples were obtained from the pumping station supplying water to the analysed network fragment and from the fire hydrant (with prior thorough rinsing) located at the end of the analysed water supply network fragment in the 
Table 2: Element concentration following subsequent migration tests.

\begin{tabular}{|c|c|c|c|}
\hline Element & Test I [ppb] & Test II [ppb] & Test III [ppb] \\
\hline $\mathrm{As}$ & $<\mathrm{LOQ}$ & $<\mathrm{LOQ}$ & $<$ LOQ \\
\hline $\mathrm{Cd}$ & $<\mathrm{LOQ}$ & $<\mathrm{LOQ}$ & $<$ LOQ \\
\hline $\mathrm{Cu}$ & $<\mathrm{LOQ}$ & $<\mathrm{LOQ}$ & $<\mathrm{LOQ}$ \\
\hline $\mathrm{Fe}$ & 246.6 & $<\mathrm{LOQ}$ & $<\mathrm{LOQ}$ \\
\hline $\mathrm{Mn}$ & 45.6 & 8.0 & 3.0 \\
\hline $\mathrm{Pb}$ & 99.8 & 162.2 & 98.1 \\
\hline $\mathrm{Zn}$ & 3.7 & 20.7 & 8.1 \\
\hline
\end{tabular}

LOQ - Limit of Quantitation (3бLOD).

vicinity of approximately $3 \mathrm{~km}$ from the pumping station. As in the previous cases, tests involved the application of inductively coupled plasma optical emission spectrometry ICP-OES JY 238 Ultrace, as well as strict adherence to the methodology of measurements.

Water samples obtained from the pumping station and the analysed end section of the network did not contain lead. However, the water from the pumping station was contaminated with a high-concentration of zinc $(2076.55$ ppb) (Table 3). It could be the result of plumbing fittings or other elements on the premises of the pumping house from which the element migrated to water (the specimen was taken via an internal galvanised sampling system and the sampling point was a regular sampling point used by on-site analytic laboratory for bacteriological examination and quality inspection of water injected into the network). The analysis leads to the conclusion that even though it is loose (it can be washed away with water stream) the sediment constitutes a protective layer against lead leaching into water. The situation, however, may undergo a change in the case of more abrupt flows than during sampling, e.g. in a water hammer.

Table 3: Element concentration in water samples from the hydrant and the pumping station.

\begin{tabular}{|c|c|c|}
\hline Element & Hydrant [ppb] & Pumping station [ppb] \\
\hline $\mathrm{As}$ & $<$ LOQ & $<$ LOQ \\
\hline $\mathrm{Cd}$ & $<$ LOQ & $<$ LOQ \\
\hline $\mathrm{Cu}$ & $<$ LOQ & $<$ LOQ \\
\hline $\mathrm{Fe}$ & $<$ LOQ & $<$ LOQ \\
\hline $\mathrm{Mn}$ & $<$ LOQ & $<$ LOQ \\
\hline $\mathrm{Pb}$ & $<$ LOQ & $<$ LOQ \\
\hline $\mathrm{Zn}$ & 5.24 & 2076.55 \\
\hline
\end{tabular}




\section{Sediment laboratory tests}

The next stage of research consisted of analysing sediment on the inside pipe wall in the aspect of structure and chemical composition. Figure 4 shows a thin layer of sediment loosely attached to the pipe material.

The form and morphology of major mineral components and chemical composition analysis of the sediment was conducted with Quanta 200 FEG Scanning Electron Microscope (SEM). Microscope analysis of the sediment evidenced that it mainly consists of calcium carbonate $\left(\mathrm{CaCO}_{3}\right)$ and oxides and hydroxides of iron and manganese, together with the mineral form of sodium chloride - halite $(\mathrm{NaCl})$.

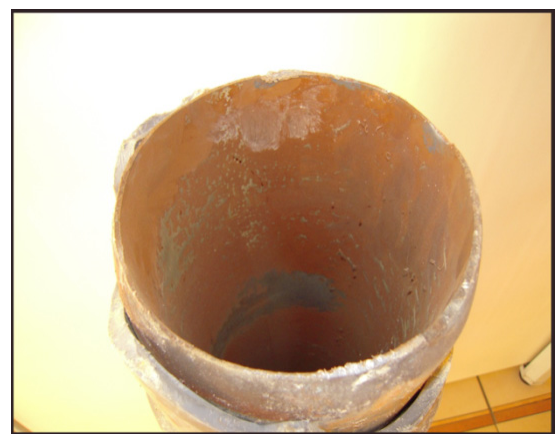

Figure 4: Inside wall of U-PVC pipe sample with sediment.
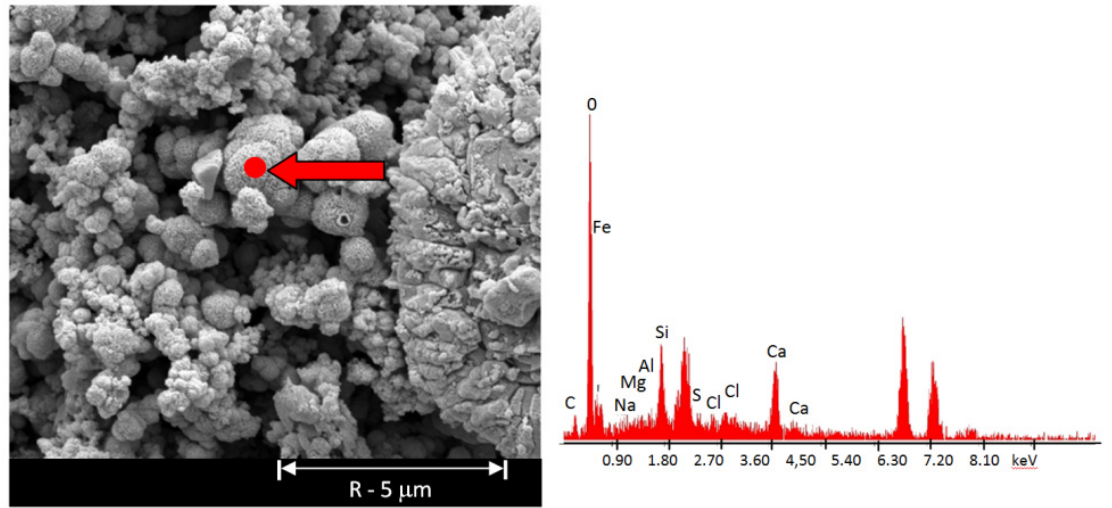

Figure 5: Sediment microstructure $-\mathrm{CaCO}_{3}$ marked in red.

Figure 5 shows a selected fragment of sediment microstructure with its chemical composition. The visible forms are "skein-like" (the red dot) composed of $\mathrm{CaCO}_{3}$, on the surface of which there are oxides of iron and quartz. 
Apart from the aforementioned compounds, the sediment includes the mineral form of sodium chloride - halite $(\mathrm{NaCl})$

\section{Summary and conclusions}

Conducted research, aimed at determining selected mechanical properties of a PVC-U pipe and the impact of the material on water quality, permits the following conclusions:

- Nearly 40 years of service of a PVC-U pipe did not result in significant degradation of the pipe material strength, neither in static tensile strength test nor in longitudinal modulus of elasticity (Young's modulus), the values of which are within the range presented in literature with reference to new pipes.

- The unit elongation at break was considerably lower than that obtained in new pipe tests, which indicates increased brittleness of the material, still, within the limit of the producer's catalogue.

- Chemical structure testing performed with the aid of infrared spectrometry manifested changes in test material that indicate material degradation, although with no significant impact on material strength. It could, nevertheless, influence migration of lead, added to PVC as a thermal stabiliser, to water.

- Migration tests demonstrated a marked impact of pipe material on water quality, i.e. the highest recorded value of lead in water samples, was $162.2 \mathrm{ppb}$ and significantly exceeded the allowable concentration of lead contained in Directive 98/83/EC of the European Union equal to $10 \mathrm{ppb}$. Leaching of this element from the pipe material into water indicates that lead compounds have been used as stabilisers in pipes.

- The concentration of chemical elements in potable water in a PVC-U pipe water distribution network did not show a sign of lead in water samples in the normal water system service. Extremely high zinc concentration $(2076.55 \mathrm{ppb})$ in the test sample from the pumping station might indicate a poor condition of plumbing fitting or other elements at the pumping station.

Analysis of sediment formed on the inside pipe wall allowed us to observe that the sediment was mainly composed of calcium carbonate, oxides and hydroxides of iron and manganese and sodium chloride. The elements detected in the analysed sediment are typical elements found in water conducted in the analysed water distribution system.

\section{Acknowledgement}

This paper was financed by statutory activity of the Faculty of Environmental Engineering, Lublin University of Technology 


\section{References}

[1] Kwietniewski M. Rurociągi polietylenowe w wodociągach i kanalizacji. Rozwój rynku w Polsce i na świecie. II Konferencja Techniczna, Ciechocinek. Inżynieria Bezwykopowa, Wydanie Specjalne ISSN pp. 17301432, 2005.

[2] Vreeburg J.H.G. Boxall J.B., Discolouration in Potable Water Distribution Systems: A Review. Water Research 41, pp. 519-529, 2007.

[3] Seth. A., Bachmann R., Boxall J., Saul A., Edyvean R., Characterisation Of Materials Causing Discolouration in Potable Water Systems. Water Science and Technology. 49 (2), pp. 27-32. Iwa Publishing, 2004.

[4] Cook S., Dal Pozzo C., PVC-A Pipes. Ductile-Brittle Transition in Failure Mode. New Tests to Evaluate the Resistance of the crack Growth. Plastic Pipes XII Milan Italy 2004.

[5] Al-Mallack M.H., Sheikheldin S.Y., Effect of Solar Radiation on the Migration of Vinyl Chloride Monomer from Unplasticized PVC Pipes. Water Research 35 (14), pp. 3283-3290, 2001.

[6] Dohnalik P., Jędrzejewski A., Efektywna Eksploatacja Wodociagów. Wyd. Lemtech Konsulting Sp. z o.o. Kraków, 2004.

[7] Jansen L.-E., Plastic Pipes for Water Supply and Sewage Disposal. Borealis, Majornas CopyPrint AB, Stockholm 2003.

[8] Frank A., Pinter G., Lang R.W., Prediction of the remaining lifetime of polyethylene pipes after up to 30 years in use. Polymer Testing 28, pp. 737745, 2009.

[9] ASTM D 2837-01a, Standard Test Method for Obtaining Hydrostatic Design Basis for Thermoplastic Pipe Materials.

[10] ISO 9080:2002, Plastic Piping and Ducting Systems - Determination of Long-Term Hydrostatic Strength of Thermoplastics Materials in Pipe Form by Extrapolation.

[11] Castiglioni G., Verzanini D., Pavan A.: Prediction of Ductile Failure in UPVC Pipes from Ceep Tests on specimens. Plastic Pipes XII Milan Italy 2004.

[12] Wolf R.: Plastic Additives. In: Ullmann's Encyclopedia of Industrial Chemistry. Vol. A20. New York, Vch Publishers Inc. 1992.

[13] Becker G., Janák K., Colmsjö A., Östman C.: Speciation of Organotin Compounds Released from Poly(Vinyl Chloride) at Increased Temperature by Gas Chromatography with Atomic Emission Detection. Journal of Chromatography A, 1997, pp. 295-306.

[14] Benaniba M.T., Belhaneche-Bensemra N., Gelbard D., Stabilization of PVC by Epoxidized Sunflower Oil in the Presence of Zinc and Calcium Stearates. Polymer Degradation And Stability 82, pp. 245-249, 2003.

[15] Reddy J.E., Hackett J.A., Advances in the Stabilization of Flexible PVC Using a Liquid Calcium-Zinc Technology, Journal Of Vinyl And Additive Technology, 8 (3), pp. 171-175, 2002.

[16] Fisch M., Bacaloglu R., Mechanism of Poly (Vinyl Chloride) Stabilisation, Plastics, Rubber and Composites 28 (3), pp. 119-124, 1999. 
[17] Benavides R., Edge M., Allen N.S., Mellor M., Harvey H., Schmets G., The Evaluation Of An Innovative Costabiliser For Poly (Vinyl Chloride) - I. Inhibition of Discolouration and Stabilisation Performance in The Polymer, Polymer Degradation and Stability 53(3), pp. 311-318, 1996.

[18] Obłój-Muzaj M., Świerz-Motysia B., Szabłowska B.: Polichlorek winylu. Wyd. Naukowo-Techniczne, Warszawa 1997.

[19] Sadiki A-I., Williams D. T., Carrier R., and Thomas B.: Pilot Study of the Contamination of Drinking Water by Organotin Compounds from PVC Materials. Chemosphere 32, pp. 2389-2398, 1996.

[20] Al-Malack M., H.: Migration of Lead from Unplasticized Polyvinyl Chloride Pipes." Journal of Hazardous Materials, B82, pp. 263-274, 2001.

[21] Al-Malack M., Sheikheldin S. Y.: Effect of Solar Radiation on the Migration of Vinyl Chloride Monomer from Unplasticized PVC Pipes. Water Research 35, pp. 3283-3290, 2001.

[22] Lasheen M.R., Sharaby C.M., El-Kholy N.G., Elsherif I.Y., and El-Wakeel S.T.: Factors Influencing Lead And Iron Release From Some Egyptian Drinking Waterpipes. Journal of Hazardous Materials 160, pp. 675-680, 2008.

[23] Kowalska B., Kowalski D., Kwietniewski M.: Organotin Compounds Leached from PVC Pipes in Water Distribution Systems, Instal 4, pp. 4246, 2009.

[24] EN 12873-1: 2003, Influence of materials on water intended for human consumption -Influence due to migration- Part 1: test method for nonmetallic and non-cementitious factory made products.

[25] EN ISO 527-1:2012. Plastics - Determination of tensile properties - Part 1: General principles.

[26] PN-EN ISO 291:2008, Plastics. Standard atmospheres for conditioning and testing.

[27] Regulation of the Minister of Health of 20 April 2010 amending the regulation on the quality of water intended for human consumption. 